\title{
Impaired Hepatocyte Regeneration in Toll-like Receptor 4 Mutant Mice
}

\author{
GRACE L. SU, MD, ${ }^{*} \dagger$ STEWART C. WANG, MD, PhD, $\ddagger$ ALIREZA AMINLARI, $\ddagger$ GEORGE L. TIPOE, MD, PhD, $\S$ \\ LARS STEINSTRAESSER, MD, $\ddagger$ and AMIN NANJI, MD, $\uparrow$
}

\begin{abstract}
Multiple lines of evidence suggest a role for endogenous lipopolysaccharides in toxin-induced liver injury. Toll-like receptor 4 has recently been implicated as a cell surface receptor important for lipopolysaccharide responsiveness. In these experiments, we sought to determine the role of toll-like receptor 4 in acute liver injury by carbon tetrachloride by utilizing the naturally occurring toll-like receptor 4 mutant and wild-type mice strains. Mice were injected with either carbon tetrachloride or the carrier. Serum transaminase levels peaked at $24 \mathrm{hr}$ after carbon tetrachloride administration for both wild-type and mutant mice, with no significant histological difference in initial liver injury between the two groups. However, an overall decrease in hepatocyte proliferation was found in the mutant mice. Examination of the liver tissue revealed significant decreases in intrahepatic expressions of proinflammatory mediators. In conclusion, our results suggest that toll-like receptor 4 is important in the hepatic regenerative response to $\mathrm{CCl}_{4}$ liver injury via its role in modulating the inflammatory response to hepatic injury.
\end{abstract}

KEY WORDS: liver; endotoxins; cytokines; hepatotoxicity.

Carbon tetrachloride is a potent hepatic toxin. It is metabolized in the liver by the cytochrome P450 system to a highly reactive trichloromethyl radical that can interact with cellular constituents, resulting in lipid peroxidation and hepatocyte necrosis. The direct effects of carbon tetrachloride in inducing liver injury are well recognized; however, other factors such as the immune response may be an important determinant of outcome to $\mathrm{CCl}_{4}$-induced liver injury. In particular, a role for endogenous lipoolysaccharide (LPS) as a cofactor in toxin-induced liver injury has been postulated (1-3). In carbon tetrachloride-treated animals, gut decontamination results in decreased liver

\footnotetext{
Manuscript received December 12, 2003; accepted March 2, 2004.

From the *Medical Serivce, Veterans Affairs Ann Arbor Health Care Systems, and Departments of $\dagger$ Medicine and $\ddagger$ Surgery, University of Michigan School of Medicine, Ann Arbor, Mchigan, USA, §Department of Anatomy, University of Hong Kong, Hong Kong, and \Department of Pathology and Laboratory Medicine, University of Pennsylvania School of Medicine, Philadelphia, Pennsylvania, USA.

Address for reprint requests: Grace L. Su, MD, University of Michigan Medical Center, 1510C MSRB I, Box 0666, $1150 \mathrm{~W}$ Medical Center Drive, Ann Arbor, Mchigan 48109-0666, USA; gsu@umich.edu.
}

injury as measured by serum transaminase levels and liver pathology $(4,5)$. Induction of LPS tolerance results in decreased hepatotoxicity from a subsequent challenge with $\mathrm{CCl}_{4}(5,6)$. The addition of LPS to $\mathrm{CCl}_{4}$ results in greater liver injury than either agent alone (7). Furthermore, treatment of rats with anti-LPS antibody (E5) also significantly decreases acute injury from carbon tetrachloride (8). In addition to its effects on injury, LPS also plays an important role in modulating the process of liver repair and regeneration. Studies of hepatic regeneration in germ-free animals and LPS-resistant animals show delayed hepatic regeneration in response to partial hepatectomy (9).

The mechanism by which LPS participates in toxininduced injury is not completely understood but is probably related to Kupffer cell activation and production of inflammatory cytokines and growth factors $(10,11)$, Within the liver, Kupffer cell activation by LPS is mediated via CD14 and toll-like receptor 4 (TLR4) $(12,13)$. Toll-like receptors are a group of evolutionarily conserved type I transmembrane proteins with leucine-rich extracellular domains and a cytoplasmic domain similar to the IL-1 
receptor. The function of these receptors is currently being elucidated and many of these receptors have been implicated as critical components of the innate immune response (14). In particular, TLR4 is important for responses to LPS. A naturally occurring TLR4 mutation occurs in the $\mathrm{C} 3 \mathrm{H} / \mathrm{HeJ}$ mouse strain and the result of this mutation is the well-described insensitivity to LPS in these animals (15). Specifically, Kupffer cells require a functioning TLR4 for normal responses to LPS (13).

In this study, we examined the role of TLR4 in toxininduced liver injury and hepatic regeneration by utilizing the TLR4 mutant $\mathrm{C} 3 \mathrm{H} / \mathrm{HeJ}$ mouse and its TLR4 wild-type control, the $\mathrm{C} 3 \mathrm{H} / \mathrm{HeOuJ}$ mouse.

\section{METHODS}

\section{Reagents}

E. coli lipopolysaccharide (LPS) (serotype 0111:B4), carbon tetrachloride and mineral oil were obtained from Sigma Chemicals (St. Louis, MO).

\section{Animal Studies}

Acute Carbon Tetrachloride Model. Eight- to 12-weekold male $\mathrm{C} 3 \mathrm{H} / \mathrm{HeOuJ}$ and $\mathrm{C} 3 \mathrm{H} / \mathrm{HeJ}$ mice were obtained from Jackson Laboratories (Bar Harbor, ME). Two identical experiments were carried out, with 36 and 60 animals, respectively. The mice were injected intraperitoneally with a single dose of either $\mathrm{CCl}_{4}(1 \mathrm{ml} / \mathrm{kg}$ diluted 1:10 with mineral oil) or mineral oil alone. Animals were sacrificed at days 1, 2, and 3 and serum and liver tissue were collected. There was no mortality at this dose of carbon tetrachloride.

Endotoxemia Model. Eight- to 12-week-old male $\mathrm{C} 3 \mathrm{H} / \mathrm{HeOuJ}$ and $\mathrm{C} 3 \mathrm{H} / \mathrm{HeJ}$ mice were injected intraperitoneally with either LPS (25 $\mu \mathrm{g} /$ mouse) or saline. Animals were sacrificed at $90 \mathrm{~min}$ and serum was obtained. Experiments were performed in accordance with National Institutes of Health guidelines and approval was obtained from the University of Michigan Animal Care and Use Committee.

\section{Measurements of ALT and TNF- $\alpha$}

Serum ALT was measured in the clinical chemistry laboratory at the University of Michigan Medical Center. Serum TNF- $\alpha$ and IL-6 levels were measured with a sandwich ELISA using antibodies from Pharmingen (San Diego, CA).

\section{Histology and Immunohistochemistry}

Liver tissue was formalin fixed and paraffin embedded prior to sectioning by Histological Consultants (Alabaster, AL). Liver sections were stained with hemotoxylin and eosin. The area of necrosis was highlighted and the area was calculated using NIH Image 1.61 Software (National Institutes of Health, Besthesda, MD).

Immunohistochemistry was performed using the ABC-based method (16) with the rabbit polyclonal anti-human Ki67 antibody (Vector Laboratories, Burlingame, CA). Parafin-embedded liver tissues were deparaffinized using xylene and rehydrated with graded ethanol solutions. To unmask the antigens on paraf- fin sections, we used the high-temperature antigen retrieval technique $(16,17)$. Following this procedure the tissue sections were blocked with normal goat serum to attenuate nonspecific binding (Vectastain Elite ABC Kit; Vector Laboratories, Burlingame, $\mathrm{CA})$ and quenched in 3\% hydrogen peroxide to block endogenous peroxidase. Sections were incubated in the presence of the primary anti-ki67 antibody. Next, the tissue sections were incubated with a biotin-conjugated secondary antibody (anti-Rabbit IgG made in goat; Vector Laboratories) and then with horseradish peroxidase-conjugated streptavidin (Vectastain Elite ABC Kit; Vector Laboratories). The chromogen Nova Red (Vector Laboratorie) was used according to manufacturer's instructions. Sections were counterstained with hematoxylin (Vector Laboratories), dehydrated with ethanol, cleared with xylene, and mounted with Mounting Medium (Richard-Allan Scientific, Kalamazoo, MI). One thousand hepatocytes were scored per slide and the result was calculated as the percentage positive cells.

\section{Real-Time Reverse Transcription Polymerase Chain Reaction (RT-PCR)}

Total RNA was isolated with the TRIzol reagent per manufacturer's instructions (Invitrogen, Carlsbad, CA). Reverse transcription was performed as previously described (18). To determine the relative amount of cytokine mRNA, amplification of sample cDNA was monitored using the Smart Cycler (Cepheid, Sunnyvale, CA) and the DNA fluorescent dye SYBR Green (Molecular Probes, Eugene OR). Primers were designed using reported sequences in GenBank. Primer sequences were as follows.
IL-6:
5' GAGGATACCACTCCCAACAGACC
TNF- $\alpha$ :

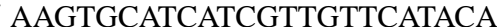
5' GGGACAGTGACCTGGACTGT
IL-10: $\quad$ 5' GCCTTATCGGAAATGATCCA
3' TTTTCACAGGGGAGAAATCG
COX-2: 5' GTGCCAATTGCTGTACAAGCAG
3' GAATGGTGCTCCAAGCTCTAC
GAPDH: 5' GTCTTCACCACCATGGAGAAG
3' CCACCTTCTTGATGTCATCAT

Primers were designed to span at least one intron if possible to minimize risk of genomic amplification. The specificity of the primers was verified using analysis of PCR product on ethidium bromide-stained agarose gel electrophoresis as well as direct sequencing of the PCR product. All real-time PCR runs included a Melting Curve analysis to assure the specificity of the product with each PCR reaction.

The validity of the semiquantitative method is confirmed by a consistent log linear correlation of $r^{2}>0.95$ between starting template RNA concentration and threshold cycle. All the values were obtained by converting the threshold cycle of the sample to relative RNA concentration based on the calibrator RNA (a random RNA sample generating a standard curve for that specific amplicon). All values are expressed as the ratio of the RNA concentration of target amplicon to the RNA concentration of a housekeeping gene (GAPDH) to equalize for cDNA concentrations between samples.

\section{Statistical Analysis}

Data were analyzed using analysis of variance and two-tail Student's $t$ test when the data had a normal distribution (Statview 
program; Abacus Concepts/SAS Institute, Cary, NC). Statistical significance was assigned at a $P$ value of $<0.05$. All figures are graphed with the mean \pm standard error.

\section{RESULTS}

\section{C3H/HeJ (TLR4 Mutant) Mice Are Insensitive to LPS}

To confirm that the $\mathrm{C} 3 \mathrm{H} / \mathrm{HeJ}$ mice were LPS resistant, mice were injected intraperitoneally either with LPS ( $25 \mu \mathrm{g} /$ mouse in saline) or with saline alone. Ninety minutes after LPS injection, blood was obtained and serum TNF- $\alpha$ levels were measured by ELISA. There was no detectable TNF- $\alpha$ in either the $\mathrm{C} 3 \mathrm{H} / \mathrm{HeOuJ}$ or the $\mathrm{C} 3 \mathrm{H} / \mathrm{HeJ}$ mice injected with saline. In the mice injected with LPS, the wild-type $\mathrm{C} 3 \mathrm{H} / \mathrm{HeOuJ}$ mice had significantly higher serum TNF- $\alpha$ levels compared to the TLR4 mutant $\mathrm{C} 3 \mathrm{H} / \mathrm{HeJ}$ mice $(6269.3 \pm 214.6$ vs. $380.7 \pm 6.6 \mathrm{pg} / \mathrm{ml})$, confirming the impaired responsiveness to endotoxin in the TLR4 mutant mice (Figure 1).

\section{Liver Injury Was Similar in TLR4 Wild-Type and Mutant Mice After $\mathbf{C C l}_{4}$ Treatment}

TLR4 wild-type and mutant mice were given a single injection of either $\mathrm{CCl}_{4}$ diluted in mineral oil or mineral oil alone. Mice injected with mineral oil had minimal elevations in serum ALT levels (Figure 2). In contrast, mice injected with $\mathrm{CCl}_{4}$ had markedly elevated ALT levels in comparison with mineral oil controls. The ALT levels peaked at day 1 and decreased thereafter, on days 2 and 3. There were no significant difference in the ALT levels between the TLR4 mutant and the wild-type groups.

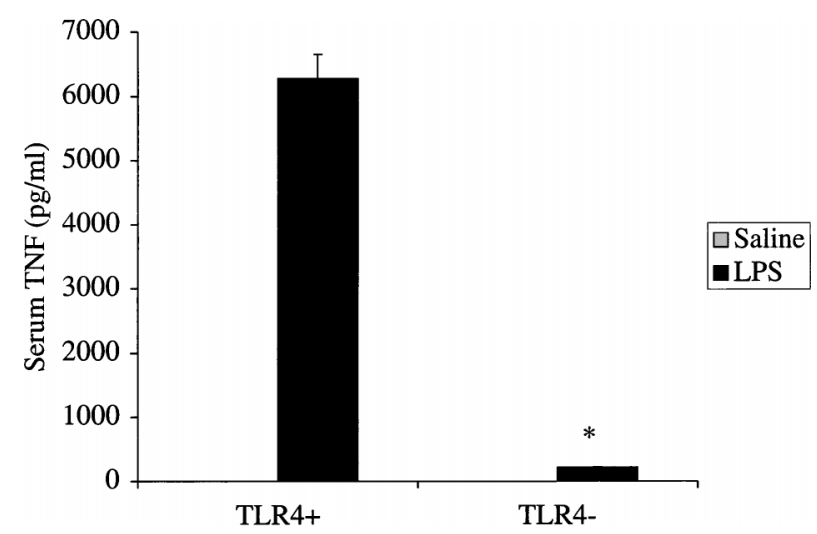

Fig 1. Serum $\mathrm{TNF}-\alpha$ levels in $\mathrm{C} 3 \mathrm{H} / \mathrm{HeJ}$ (TLR4+) and $\mathrm{C} 3 \mathrm{H} / \mathrm{OuJ}$ (TLR4-) mice $90 \mathrm{~min}$ after intraperitoneal injection of either LPS or saline. There was no detectable TNF- $\alpha$ in response to saline in either strain of animals; however, significantly more TNF- $\alpha(* P<0.01$, TLR4+ vs. TLR4-) was detected in the $\mathrm{C} 3 \mathrm{H} / \mathrm{HeOuJ}$ (TLR4+; wildtype) mice compared to the $\mathrm{C} 3 \mathrm{H} / \mathrm{HeJ}$ (TLR4-; mutant) mice injected with LPS. $n=2$ mice per group.

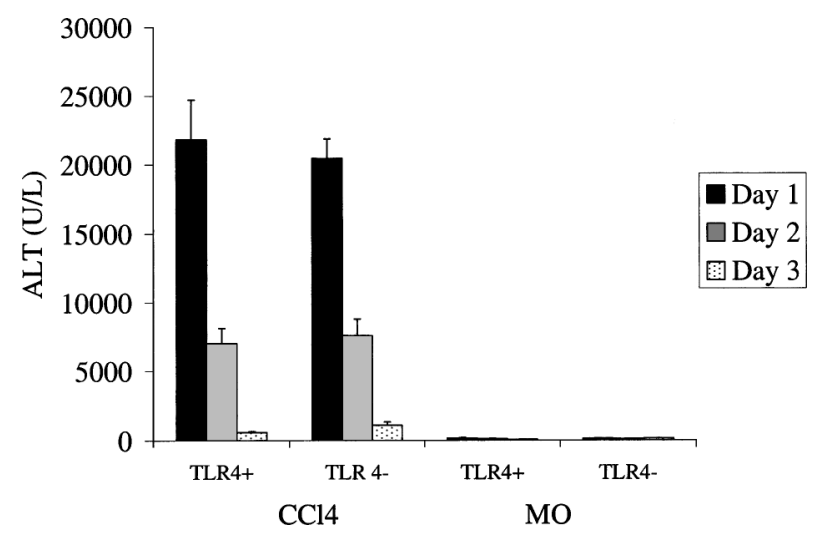

Fig 2. Serum ALT levels over time in $\mathrm{C} 3 \mathrm{H} / \mathrm{HeOuJ}$ (TLR4 wild-type) and $\mathrm{C} 3 \mathrm{H} / \mathrm{HeJ}$ (TLR4 mutant) mice injected with either $\mathrm{CCl}_{4}$ or $\mathrm{MO}$ (mineral oil control). These are the composite results from the two experiments; $n=8$ animals per group.

The TLR4 mutant mice had no discernible abnormality of liver histology as evidenced by normal histology after mineral oil in both TLR4 mutant and wild-type mice. After carbon tetrachloride the characteristic centrilobular necrosis was found and was most marked on day 1, with improvement by day 3 . There were no significant differences in the amount of necrosis seen in TLR4+ and TLR4 mutant groups (Figure 3).

\section{Effect of TLR4 on the Hepatic Regenerative Response}

To assess the effect of TLR4 on hepatic regeneration after acute liver injury, we measured hepatocyte proliferation using an antibody against Ki67. This antibody detects a nuclear antigen that is present in proliferating cells (G1, S, G2 and M) but absent in quiescent cells (G0) and necrotic cells $(19,20)$. Both TLR4 wild-type and mutant animals had little hepatocyte proliferation in response to the vehicle control (mineral oil). In contrast, after carbon

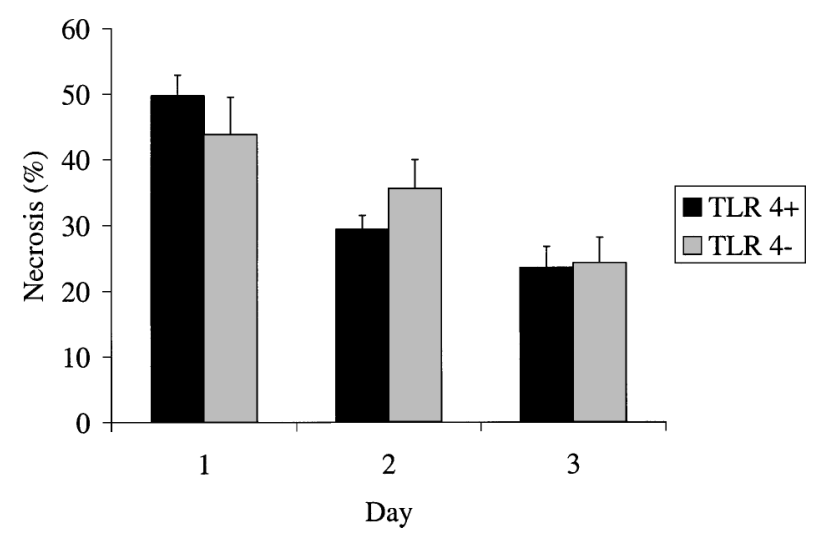

Fig 3. Percentage necrosis of liver section using image analysis. $n=5$ /group. 


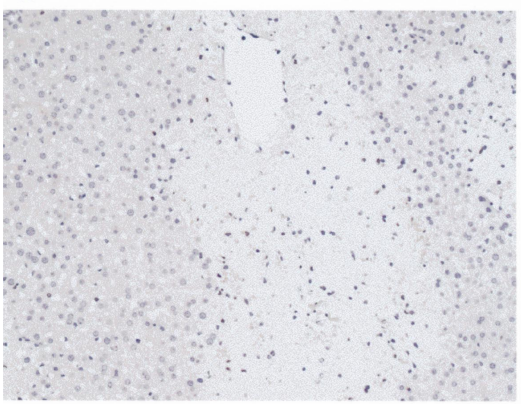

C

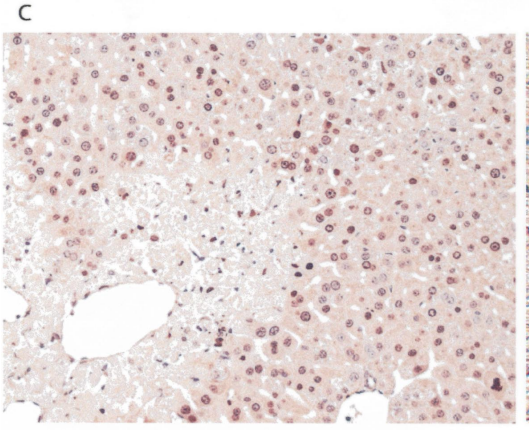

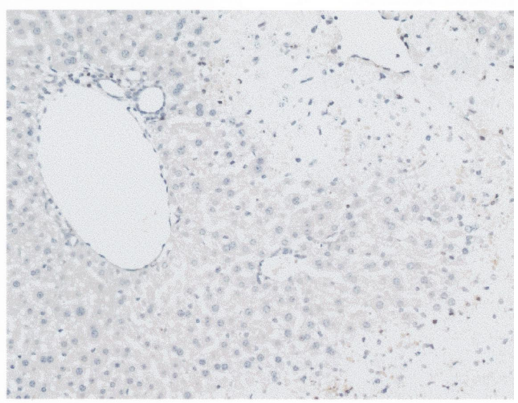

D

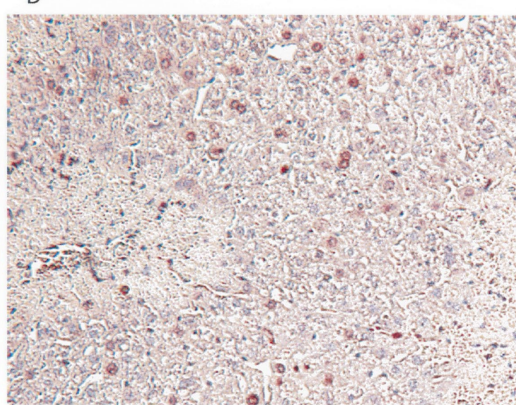

$\mathrm{F}$

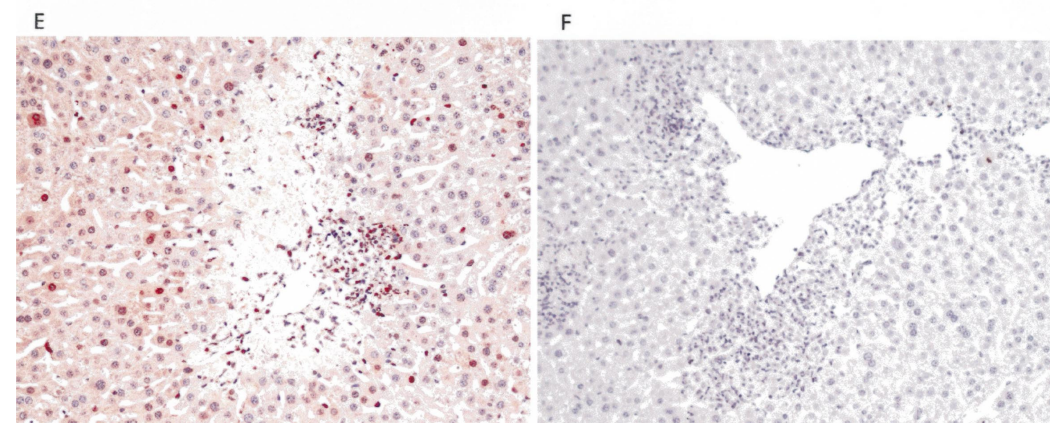

Fig 4. Ki67 staining of liver tissue from TLR4 wild-type (A, C, E) and TLR4 mutant (B, D, F) mice day 1 (A and $\mathrm{B})$, day $2(\mathrm{C}$ and $\mathrm{D})$, and day $3(\mathrm{E}$ and $\mathrm{F})$ after carbon tetrachloride.

tetrachloride injection, marked hepatocyte proliferation was seen in the hepatocytes surrounding the necrotic areas (Figure 4). The greatest degree of hepatocyte proliferation was seen on day 2 and had decreased by day 3 in both of the $\mathrm{CCl}_{4}$-treated groups. At the peak of proliferation (day 2), there was a tendency toward decreased proliferation in the mutant mice that persisted on day 3 (Table 1). In particular, there was significantly less proliferation in the TLR4 mutant mice after $\mathrm{CCl}_{4}(P<0.05)$. Thus the key conclusion was that TLR4 mutant mice had significantly less hepatocyte proliferation after carbon tetrachloride.

\section{Cytokine Experession in $\mathbf{C C l}_{\mathbf{4}}$ Animals}

Because cytokines such as IL- 6 , TNF- $\alpha$, and IL-10 have been implicated as important mediators of hepatic regeneration $(21,22)$, we examined the intrahepatic levels of these cytokines by real-time polymerase chain reaction (Table 2). For all of the cytokines examined, the highest levels of expression were on day 1 , which reflected the period at which the greatest liver injury was observed. Levels of proinflammatory cytokines decreased gradually after day 1 . There was an overall trend toward lower IL-

Table 1. Percentage of Hepatocytes Staining Positive for KI67 AFTER CCL4 IN TLR4 WiLD-TyPE AND MutANT MiCE

\begin{tabular}{lcc}
\hline & TLR4 wild type & TLR4 mutant \\
\hline Day 1 & $0.6 \pm 0.3$ & $0.7 \pm 0.2$ \\
Day 2 & $39.4 \pm 11.6$ & $15.3 \pm 7.0$ \\
Day 3 & $16.0 \pm 4.5$ & $0.4 \pm 0.3^{*}$ \\
\hline
\end{tabular}

Note. $n=3$ to 5 per group per time point. $* P<0.05$ TLR 4 wildtype vs. mutant mice. 
TABLE 2. INTRAHEPATIC MRNA LEVELS OF (A) IL-6, (B) TNF- $\alpha$, (C) IL-10, AND (D) COX-2 AFTER CCL4 IN TLR WILD-TYPE AND MutANT Mice

\begin{tabular}{lcc}
\hline & TLR4 wild type & TLR4 mutant \\
\hline A. I L-6 & & \\
Day 1 & $8.41 \pm 2.10$ & $7.18 \pm 5.57$ \\
Day 2 & $3.33 \pm 1.68$ & $0.98 \pm 0.35$ \\
Day 3 & $0.24 \pm 0.05$ & $0.11 \pm 0.03^{*}$ \\
B. TNF- $\alpha$ & \\
Day 1 & & \\
Day 2 & $20.25 \pm 1.78$ & $12.27 \pm 6.41$ \\
Day 3 & $8.15 \pm 2.00$ & $10.02 \pm 3.48$ \\
C. IL-10 & $6.59 \pm 0.22$ & $3.18 \pm 0.69^{*}$ \\
Day 1 & & \\
Day 2 & $16.15 \pm 3.14$ & $9.56 \pm 5.01$ \\
Day 3 & $5.37 \pm 0.49$ & $4.44 \pm 1.39$ \\
D. COX-2 & $17.00 \pm 3.36$ & $14.45 \pm 3.00$ \\
Day 1 & & \\
Day 2 & $111.69 \pm 40.65$ & $36.19 \pm 15.80$ \\
Day 3 & $90.55 \pm 18.72$ & $12.6 \pm 5.18^{*}$ \\
\hline Note $n=3$ 3 5/grop. & & $12.4 \pm 3.75$ \\
\hline
\end{tabular}

Note. $n=3$ to $5 /$ group.

6 and TNF- $\alpha$ mRNA levels in TLR4 mutant mice, which was significant on day 3 after $\mathrm{CCl}_{4}$ injection. The decrease in TNF- $\alpha$ and IL-6 expression occurred concurrently with a decrease in hepatic proliferation at this time period. The pattern of IL-10 mRNA expression was different from that seen with IL- 6 and TNF- $\alpha$. IL-10 mRNA levels declined rapidly on day 2 but increased on day 3. Although no significant differences in IL-10 mRNA levels were noted between TLR4 wild-type and mutant mice, there was a trend toward lower IL-10 mRNA expression in the TLR4 mutant mice (Table 2C).

We also examined the expression of cyclooxygenase 2 (COX-2) mRNA, as this inflammatory mediator has also been found to be important in liver regeneration (23). Similar to the observations made with the cytokines, COX-2 mRNA levels were greatest on day 1 and decreased gradually thereafter. Overall, there was a trend toward lower COX-2 mRNA levels in TLR4 mutant mice that was particularly significant on day 2 (Table 1D).

In addition to evaluating intrahepatic mRNA expression, we also examined serum levels of IL-6 and TNF$\alpha$ that reflect both hepatic and extrahepatic expressions of these cytokines (Figure 5). Similar to what was observed with intrahepatic expression of these cytokines, the highest serum levels of IL- 6 and TNF- $\alpha$ were noted on day 1 and decreased thereafter, on days 2 and 3. The IL- 6 serum levels reflected the IL- 6 mRNA levels in the liver, with a general trend toward lower serum levels of IL-6 in the TLR4 mutants, which was significant on day 3 after carbon tetrachloride. There was no difference in TNF- $\alpha$ levels between the groups.
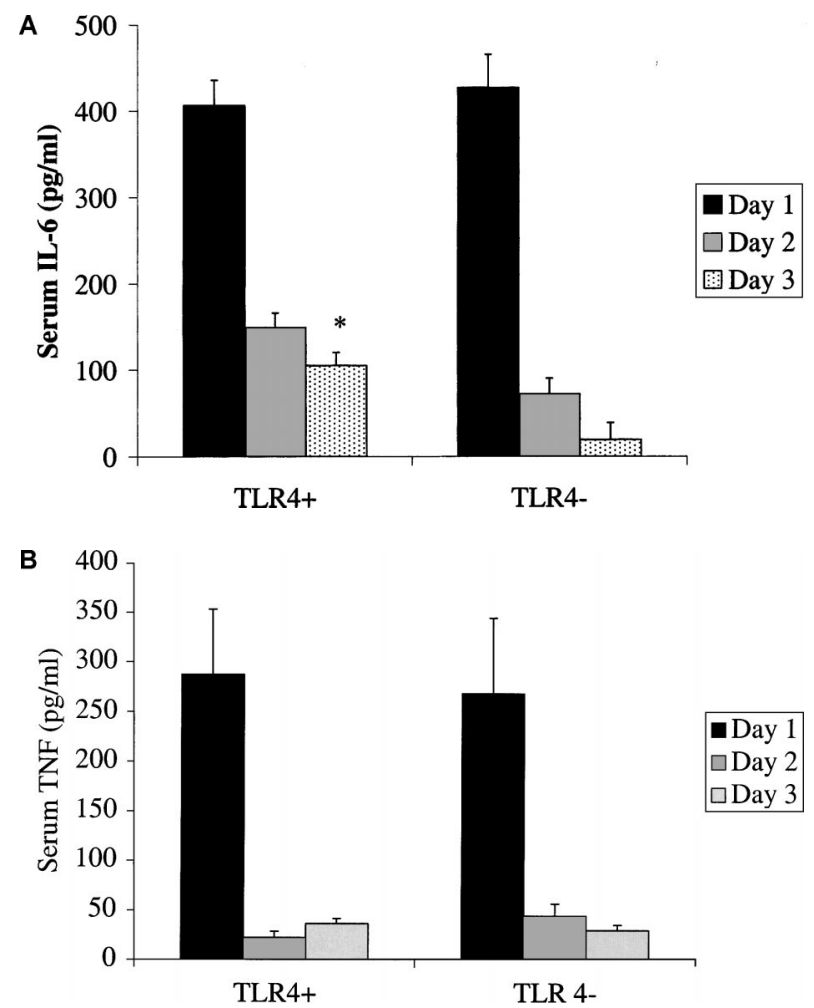

Fig 5. (A) Serum IL-6 levels and (B) serum TNF- $\alpha$ levels in C $3 \mathrm{H} / \mathrm{HeOuJ}$ (TLR4 wild-type) and $\mathrm{C} 3 \mathrm{H} / \mathrm{HeJ}$ (TLR4 mutant) mice injected with either $\mathrm{CCl}_{4}$ or mineral oil. ${ }^{*} P<0.05$ TLR4 mutant vs. wild-type. $n=4$ to 6/group.

\section{DISCUSSION}

In this study, we examined two important aspects of carbon tetrachloride-induced liver injury: the initial necrotic injury and the hepatic regenerative response. We showed that the severity of necrotic liver injury secondary to carbon tetrachloride administration was not affected by the absence of a functioning TLR4 receptor. $\mathrm{C} 3 \mathrm{H} / \mathrm{HeJ}$ (TLR4 mutant) mice had a similar degree of liver injury with carbon tetrachloride compared to $\mathrm{CeH} / \mathrm{HeOuJ}$ (TLR4 wildtype) mice. Both groups of animals exhibited similar degrees of liver injury as assessed by both histological and biochemical criteria. In contrast, the hepatocyte proliferative response was blunted in the TLR4 mutant mice. With respect to the mechanisms involved in the initial liver injury and considering that TLR4 is important for LPS responses, we suggest that downstream pathways that are independent of TLR4 are important for mediating the initial liver injury under the experimental conditions used in the present study. It is important to point out that our results differ from previous studies using anti-LPS antibodies where administration of anti-LPS antibody (E5) reduced serum AST levels by $47 \%(P<0.05)$ and $54 \%$ 
$(P<0.05)$ at 36 and $48 \mathrm{hr}$ after $\mathrm{CCI}_{4}$ administration in rats (8). These studies, however, evaluated the LPSmediated toxicity rather than downstream signaling pathways of LPS signaling.

Perhaps of greater importance is that clear differences in carbon tetrachloride-induced liver injury can be seen between mice and rats. An important role for TNF- $\alpha$ in mediating acute liver injury secondary to carbon tetrachloride administration is well demonstrated in the rat. Administration of soluble TNF receptors in the rat significantly decreased acute hepatic injury(24). In contrast, neutralizing antibodies to $\mathrm{TNF}-\alpha$ do not ameliorate acute liver injury in the mouse (25). However, a decrease in regenerative response in mice is noted with TNF- $\alpha$ antibodies (25). Similarly, TNF receptor-1 deficient mice show a decreased regenerative response to $\mathrm{CCI}_{4}$ but exhibit no difference in acute liver injury (26).

Our observation that the hepatocyte proliferative response was blunted in the TLR4 mutant mice supports a role for TLR4 in the hepatic regenerative response to carbon tetrachloride-induced liver injury and is consistent with previous studies on the effects of LPS on hepatic regeneration. After partial hepatectomy, a delay in liver regeneration is noted in $\mathrm{C} 3 \mathrm{H} / \mathrm{HeJ}$ mice (9) compared to conventional mice. Similarly, a decrease in liver regeneration is also found in germ-free animals, suggesting that production of LPS by endogenous bacterial flora is important in hepatic regeneration (9). The mechanism by which this occurs is likely related to the interplay of LPS with Kupffer cells and production of cytokines which are critical for liver regeneration.

Importantly, our results are similar to those seen in studies in mice in which there is an absence of IL- 6 or TNF- $\alpha$ mediated signaling in response to acute liver injury. The need for new hepatocytes is often triggered by the loss of liver tissue as a consequence of liver toxicity such as is seen with carbon tetrachloride. Current evidence suggests that cytokines such as TNF- $\alpha$ and IL-6 are centrally involved in the regeneration of new hepatocytes (27). Based on results obtained in IL-6-deficient and TNF RI-deficient animals, a model has been constructed to define the role of TNF- $\alpha$ and IL-6 in liver regeneration $(21,28)$. After liver injury, TNF- $\alpha$ is initially elevated and then activates IL-6, most likely via NF- $\kappa$ B. Our results showed significantly decreased intrahepatic expression of both IL- 6 and TNF- $\alpha$ in the TLR4 mutant mice on day 3 after $\mathrm{CCI}_{4}$ administration that coincided with deficient liver regeneration. Similarly decreased systemic levels of IL- 6 were also seen. The functional relevance of IL- 6 as a terminal mediator of liver regeneration after toxin or other forms of liver injury has been confirmed in several studies $(28,29)$. Our data support the hypothesis that TLR4 mediates liver regeneration through its modulation of IL-6 production. Serum TNF$\alpha$ levels were not significantly different between TLR4 wild-type and mutant mice; however, this may reflects contributions from extrahepatic sources of $\mathrm{TNF}-\alpha$ after $\mathrm{CCl}_{4}$ administration. Although most of the $\mathrm{CCl}_{4}$ is metabolized in the liver, extrahepatic sites of metabolism are recognized and can also contribute to cytokine production as a result of local injury (30).

Another proinflammatory mediator that was significantly decreased on day 2 was cyclooxygenase 2. COX-1 and $\mathrm{COX}-2$ catalyze the first step in prostaglandin synthesis. COX-1 is constitutively expressed in many tissues and is involved in the "housekeeping" functions through production of prostaglandins. COX-2, in contrast, is the inducible form of $\mathrm{COX}$ and increased expression occurs in response to inflammatory stimuli and growth factors (31). Recent studies have shown that prostaglandins produced by COX-2 are important in liver regeneration after partial hepatectomy. In particular, mice deficient in COX-2 show impaired liver regeneration (23). Our results, which demonstrated decreased mRNA levels for COX-2 at a time point when signals for liver regeneration are crucial, suggest that decreased expression of this inflammatory mediator may contribute to the decreased hepatocyte proliferation seen in TLR4 mutant mice after $\mathrm{CCl}_{4}$ induced liver injury. In fact, the overall significant decreases in the inflammatory mediators, IL-6, TNF- $\alpha$, and COX-2, suggest that TLR4-mediated signaling is important in modulating liver regeneration after toxin-induced liver injury.

\section{ACKNOWLEDGMENTS}

This research was supported by a Veterans Administration Merit Award (G.L.S.) and National Institutes of Health Grants GM60205 (S.C.W.) and DK53296 (G.L.S.). We would like to thank Mita Ghosh and E Chiao Huang for their technical assistance and Sybil Boone for her assistance in preparing the manuscript.

\section{REFERENCES}

1. Nolan JP: The role of endotoxin in liver injury. Gastroenterology 69:1346-1356, 1975

2. Nolan JP: Intestinal endotoxins as mediators of hepatic injury-an idea whose time has come again. Hepatology 10:887-891, 1989

3. Roth RA, Harkema JR, Pestka JP, Ganey PE: Is exposure to bacterial endotoxin a determinant of susceptibility to intoxication from xenobiotic agents? Toxicol Appl Pharmacol 147:300-311, 1997

4. Nolan JP, Leibowitz AI: Endotoxin and the liver III. Modification of acute carbon tetrachloride injury by polymyxin B, an antiendotoxin. Gastroenterology 75:445-449, 1978

5. Williams J: Carbon tetrachloride hepatotoxicity in endotoxin tolerant and polymixin B treated rats. Int J Immunopharm 10:975-980, 1988

6. Nolan JP, Ali MV: Endotoxin and the liver: II. Effect of tolerance on carbon tetrachloride-induced liver injury. J Med 4:28-38, 1973 
7. Chamulitrat W, Jordan S, Mason R: Nitric oxide production during endotoxin shock in carbon tetachloride-treated rats. Mol Pharm 46:391-397, 1994

8. Czaja MJ, Xu J, Ju J, Alt E, Schmiedeberg P: Lipopolysaccharideneutralizing antibody reduces hepatocyte injury from acute hepatotoxin administration. Hepatology 19:1282-1289, 1994

9. Cornell RP, Liljequist BL, Bartizal KF: Depressed liver regeneration after partial hepatectomy of germ-free, athymic and lipopolysaccharide-resistant mice. Hepatology 11:916-922, 1990

10. Edwards MJ, Keller BJ, Kauffman FC, Thurman RG: The involvement of Kupffer cells in carbon tetrachloride toxicity. Toxicol Appl Pharmacol 119:275-279, 1993

11. Olthoff, K.M. (2002) Molecular Pathways of Regeneration and Repair after Liver Transplantation. World J Surg 26.

12. Su GL, Goyert SM, Fan MH, Aminlari A, Gong KO, Klein RD, Myc A, Alarcon WH, Steinstraesser L, Remick, DG, Wang SC: Activation of human and mouse Kupffer cells by lipopolysaccharide is mediated by CD14. Am J Physiol Gastrointest Liver Physiol 283:G640-G645, 2002

13. Su G, Klein R, Aminlari A, Zhang H, Steinstraesser L, Alarcon W, Remick D, Wang S: Kupffer cell activation by lipopolysaccharide in rats: role for lipopolysaccharide binding protein and toll-like receptor 4. Hepatology 31:932-936, 2000

14. Akira S: Mammalian Toll-like receptors. Curr Opin Immunol 15:511,2003

15. Poltorak A, He X, Smirnova I, Liu M, Van Huffel C, Du X, Birdwell D, Alejos E., Silva M, Galanos C, Freudenberg M, RicciardiCastagnoli P, Layton B, Beutler B: Defective LPS signalling in $\mathrm{C} 3 \mathrm{H} / \mathrm{HeJ}$ and $\mathrm{C} 57 \mathrm{BL} / 10 \mathrm{ScCr}$ Mice: mutations in Tlr4 gene. Science 282:2085-2088, 1998

16. Cattoretti G, Pileri S, Parravicini C, Becker MH, Poggi S, Bifulco C, Key G, D'Amato L, Sabattini E, Feudale E, et al.: Antigen unmasking on formalin-fixed, paraffin-embedded tissue sections. J Pathol 171:83-98, 1993

17. Shi SR, Imam SA, Young L, Cote RJ, Taylor CR: Antigen retrieval immunohistochemistry under the influence of $\mathrm{pH}$ using monoclonal antibodies. J Histochem Cytochem 43:193-201, 1995

18. Su GL, Freeswick PD, Geller DA, Wang Q, Shapiro RA, Wan YH, Billiar TR, Tweardy DJ, Simmons RL, Wang SC: Mol1cular cloning, characterization, and tissue distribution of rat lipopolysaccharide binding protein. Evidence for extrahepatic expression. J Immunol 153:743-752, 1994

19. Petroll WM, Jester JV, Bean J, Cavanagh HD: Labeling of cycling corneal endothelial cells during healing with a monoclonal antibody to the Ki67 antigen (MIB-1). Cornea 18:98-108, 1999

20. Farinati F, Cardin R, D'Errico A, De Maria N, Naccarato R, Cecchetto A, Grigioni W: Hepatocyte proliferative activity in chronic liver damage as assessed by the monoclonal antibody MIB1 Ki67 in archival material: The role of etiology, disease activity, iron, and lipid peroxidation. Hepatology 23:1468-1475, 1996

21. Fausto N: Liver regeneration. J Hepatol 32:19-31, 2000

22. Rai RM, Loffreda S, Karp CL, Yang SQ, Lin HZ, Diehl AM: Kupffer cell depletion abolishes induction of interleukin-10 and permits sustained overexpression of tumor necrosis factor alpha messenger RNA in the regenerating rat liver. Hepatology 25:889-895, 1997

23. Casado M, Callejas NA, Rodrigo J, Zhao X, Dey SK, Bosca L, Martin-Sanz P: Contribution of cyclooxygenase 2 to liver regeneration after partial hepatectomy. FASEB J 15:2016-2018, 2001

24. Czaja MJ, Xu J, Alt E: Prevention of carbon tetrachloride-induced rat liver injury by soluble tumor necrosis factor receptor. Gastroenterology 108:1849-1854, 1995

25. Bruccoleri A, Gallucci R, Germolec D, Blackshear P, Simeonova $\mathrm{P}$, Thurman R, Luster M: Induction of early-immediate genes by tumor necrosis factor $\alpha$ contribute to liver repair following chemical induced hepatotoxicity. Hepatology 25:133-141, 1997

26. Yamada Y, Fausto N: Deficient liver regeneration after carbon tetrachloride injury in mice lacking type 1 but not type 2 tumor necrosis factor receptor. Am J Pathol 152:1577-1589, 1998

27. Grisham JW, Coleman WB: Molecular regulation of hepatocyte generation in adult animals. Am J Pathol 161:1107-1110, 2002

28. Streetz KL, Luedde T, Manns MP, Trautwein C: Interleukin 6 and liver regeneration. Gut 47:309-312, 2000

29. Cressman DE, Greenbaum LE, DeAngelis RA, Ciliberto G, Furth EE, Poli V, Taub R: Liver failure and defective hepatocyte regeneration in interleukin-6-deficient mice. Science 274:1379-1383, 1996

30. Tjalve H, Lofberg B: Extrahepatic sites of metabolism of carbon tetrachloride in rats. Chem Biol Interact 46:299-316, 1983

31. Smith WL, Langenbach R: Why there are two cyclooxygenase isozymes. J Clin Invest 107:1491-1495, 2001 